\title{
PENGARUH KUALITAS PELAYANAN TERHADAP KEPUASAN MASYARAKAT PEMBUAT KARTU KUNING (AK-I) PADA DINAS TENAGA KERJA KABUPATEN TANGERANG
}

Ditulis Oleh : Wina Elvariana ${ }^{1}$ H. Ahmad Murodi, Drs.,MM ${ }^{2}$, Seno Santoso, SH.,MM.,M.Kn ${ }^{3}$ Dosen Tetap Yayasan Prodi Ilmu Administrasi Negara FISIP Universitas Islam Syekh Yusuf E-mail:winaelvariana97@gmail.com

\begin{abstract}
ABSTRAK
Penelitian ini berjudul "Pengaruh Kualitas Pelayanan Terhadap Kepuasan Masyarakat Pembuat Kartu Kuning (AK-I) Pada Dinas Tenaga Kerja Kabupaten Tangerang”. Sampel yang digunakan Sampel kuota, Peneliti mengambil sampel 100 orang, responden pada penelitian ini adalah masyarakat pembuat kartu kuning (AK-I) pada Dinas Tenaga Kerja Kabupaten Tangerang. Dalam Penelitian ini metode yang digunakan adalah metode kuantitatif dengan pendekatan asosiatif, teknik pengumpulan data yang digunakan adalah studi kepustakaan dan studi lapangan dengan cara observasi, angket dan wawancara. Data yang diperoleh dianalisis menggunakan program SPSS (Statisical Product and Solution Service) for Windows Versi 24 dengan menggunakan teknik korelasi dan dengan metode pearson product moment dan kemudian dilanjutkan dengan pengujian regresi.
\end{abstract}

Kata Kunci : Kualitas pelayanan, Kepuasan Masyarakat

\begin{abstract}
"The influence of Service Quality on the Satification of the Community of Yellow Card Makers (AK-I) at the Labor Service of Tangerang Regency. The Sampel used quota samples, researchers took a sample of 100 people, respondents in this study was the community of yellow card makers (AK-I) at the Labor Service of Tangerang Regency.In this research, the method used quantitative method with assosiative approach. Data collection technique used is literature study and field study by way of observation, questionnaire, and interview. The data obtained were analyzed using the SPSS (Statisical Product and Solution Service) for Windows Versi on 24 using corellation techiques and with the person product with regression testing.
\end{abstract}

Keyword :Service Quality, Comunity Satisfaction

\section{A. LATAR BELAKANG}

Penyelenggaraan pelayanan publik merupakan salah satu upaya dari pemerintah demi terwujudnya kesejahteraan, sebagaimana yang menjadi tujuan negara indonesia yang tercantum dalam pembukaan UUD 1945 dan fungsi dari administrasi negara. Dengan kata lain, pelayanan 
publik adalah salah satu konsep untuk mencapai apa yang dikehendaki oleh masyarakat dan negara. Dalam pasal 5 UU No.25 Tahun 2009 tentang pelayanan publik meliputi pelayanan publik ruang lingkup pelayanan publik meliputi pelayanan barang dan jasa publik serta pelayanan administrasi yang diatur dalam peraturan perundang-undang. UU No.25 Tahun 2009 tentang pelayanan publik merupakan acuan bagi seluruh penyelenggaraan publik sesuai dengan kewenangannya.

Dinas Tenaga Kerja merupakan suatu lembaga pemerintah yang bergerak dibidang ketenagakerjaan dari tahun ke tahun terus berupaya untuk meningkatkan kualitas pelayanan di bidang ketenagakerjaan sebagai sarana dan prasarana masyarakat. Fungsi pelayanan publik merupakan salah satu fungsi fundamental yang harus diemban pemerintah baik ditingkat pusat maupun tingkat daerah. Mengingat fungsi utama pemerintah yaitu melayani masyarakat, maka pemerintah perlu berupaya meningkatkan kualitas pelayanan salah satunya pelayanan pembuatan kartu kuning (AK-I).

Kartu pencari kerja atau yang lebih dikenal dengan kartu kuning (AK-I) merupakan kartu tanda bukti pendaftar pencari kerja yang digunakan oleh para pencari kerja sebagai keterangan mereka belum dan sedang mencari kerja dan karu kuning (AK-I) juga dijadikan sebagai salah satu syarat untuk melamar pekerjaan disebuah perusahaan atau instansi baik dinegeri maupun swasta, meskipun tidak semua perusahaan atau instansi mengajukan syarat untuk memiliki pencari kerja yang dihasilkan agar digunakan untuk statistik jumlah pencari kerja pada tahun yang bersangkutan agar dapat dibandingkan dengan jumlah lapangan pekerjaan yang ada, sehingga dapat menjadi koreksi atau landasan untuk meningkatkan jumlah lapangan kerja di indonesia. Dinas Tenaga Kerja (Dinasker) merupakan instansi yang bertanggung jawab untuk menangani masalah pelayanan pembuatan kartu kuning (AK-I) di indonesia. Pada kenyataannya pelayanan publik oleh aparatur pemerintah dewasa ini masih banyak dijumpai kelemahan sehingga belum dapat memenuhi kualitas yang di harapkan masyarakat. Oleh karena itu peneliti mengadakan penelitian lebih lanjut untuk mengetahui bagaimana pengaruh kualitas pelayanan terhadap kepuasan masyarakat pada Dinas Tenaga Kerja Kabupaten Tangerang. Berdasarkan hasil pengamatan sementara peneliti, di antaranya:

1. Keterbatasan sarana dan prasarana pada Dinas Tenaga Kerja Kabupaten Tangerang.

Keterbatasan sumber daya manusia melaksanakan pelayanan, seperti dibatasinya nomor antrian untuk masyarakat pembuat kartu kuning (AK-I) pada Dinas Tenaga Kerja Kabupaten Tangerang. 2. Pegawai kurang ramah dalam pelayanan kartu kuning (AK-I) pada Dinas Tenaga kerja 
Kabupaten Tangerang.

\section{B. Tinjauan Teori}

\section{a. Pengertian Administrasi, Administrasi Negara dan Manajemen}

Menurut Sondang P.Siagian dalam Inu Kencana (2015:5) mengatakan bahwa "Administrasi adalah keseluruhan proses pelaksanaan dari keputusan-keputusan yang telah diambil dan pelaksanaan itu pada umumnya dilakukan oleh dua orang manusia atau lebih untuk mencapai tujuan yang telah ditentukan sebelumnya”. Menurut George J.Gordon (Inu Kencana, 2015:33) bahwa "Administrasi Negara dapat dirumuskan sebagai seluruh proses baik yang dilakukan organisasi maupun perseorangan yang berkaitan dengan penerapan atau pelaksanaan hukum dan peraturan yang dikeluarkan oleh badan legislatif, eksekutif, serta pengadilan. Menurut Terry dalam Hasibuan (2011:2) mengatakan bahwa "Manajemen adalah suatu proses yang khas yang terdiri dari tindakan- tindakan perencanaan, pengorganisasian, pengarahan, dan pengendalian yang dilakukan untuk menentukan serta mencapai sasaran- sasaran yang telah ditentukan melalui pemanfaatan sumber daya manusia dan sumber-sumber lainnya".

\section{b. Pengertian Kualitas}

Groetsh dan Davis (Hardiyansyah, 2018:49) bahwa "Kualitas merupakan suatu kondisi dinamis yang berhubungan dengan produk, jasa, proses, dan lingkungan yang memenuhi atau melebihi harapan”. Menurut Wijaya dalam Nuraeni (2016:7) mengatakan bahwa "Kualitas adalah sesuatu yang diputuskan oleh pelanggan. Artinya, kualitas didasarkan pada pengalaman aktual pelanggan atau konsumen terhadap produk atau jasa yang diukur berdasarkan persyaratan-persyaratan tersebut".

\section{c. Pengertian Pelayanan}

Menurut Poerwadarminta dalam Hardiyansyah (2018:140) pelayanan berasal dari kata layan yang berarti membantu mengurus apa-apa yang diperlukan seseorang. Menurut Sinambela, dkk dalam Agus Hipludin (2017:106) bahwa "Pelayanan adalah setiap kegiatan yang menguntungkan dalam suatu kumpulan atau kesatuan, dan menawarkan kepuasan meskipun hasilnya tidak terikat pada suatu produk secara fisik".

\section{d. Pengertian Kualitas Pelayanan}

Menurut Sampara (Hardiyansyah,2018:49) bahwa "Kualitas pelayanan adalah pelayanan yang diberikan kepada pelanggan sesuai dengan standar pelayanan yang telah dibakukan sebagai pedoman dalam memberikan layanan.Lovelock dalam Arif Nugraheni (2015:16) mengatakan bahwa "Kualitas Pelayanan merupakan tingkat keunggulan yang diharapkan 
dan pengendalian atas tingkat keunggulan tersebut untuk memenuhi harapan pelanggan”.

\section{e. Faktor-Faktor Yang Mempengaruhi Kualitas Pelayanan}

Menurut Atep Adya Barata (Arif Nugraheni,2015:14) bahwa“" Kualitas pelayanan terbaik menjadi dua bagian yaitu kualitas pelayanan internal dan eksternal". Masing-masing bagian tersebut dipengaruhi oleh beberapa faktor yang cukup penting, yaitu sebagai berikut :

1. Faktor yang mempengaruhi kualitas pelayanan internal (interaksi pegawai organisasi), yaitu pola manajemen umum organisasi, penyediaan fasilitas pendukung, pengembangan sumber daya manusia, iklim kerja dan keselarasan hubungan kerja, serta pola intensif.

2. Faktor yang mempengaruhi kualitas pelayanan eksternal (pelanggan eksternal), yaitu pola layanan dan tata cara penyediaan layanan, pola layanan distribusi jasa, pola layanan penjualan jasa, dan pola layanan dalam penyampaian jasa.

\section{f. Indikator Kualitas Pelayanan}

Dimensi atau ukuran kualitas pelayanan menurut Tjiptono dalam Hardiyansyah (2018:73)

\section{Bukti Langsung (Tangible)}

2. Kehandalan (Reliability)

3. Daya Tanggap (Responsiveness)

4. Jaminan (Assurance)

5. Empati (Empathy)

Pengertian Kepuasan Pelanggan Menurut Nasution M.N dalam Arif Nugraheni (2015:21) "Kepuasan pelanggan adalah suatu keadaan dimana kebutuhan, keinginan, dan harapan pelanggan dapat terpenuhi melalui produk yang dikonsumsi”. Schnaars (Arif Nugraheni, 2015:21) menyebutkan bahwa : Terciptanya kepuasan pelanggan dapat memberikan manfaat, diantaranya : hubungan antara pelanggan dengan instansi menjadi harmonis, memberikan dasar yang baik bagi pembeli (pemakaian) ulang, terciptanya loyalitas dari pelanggan serta terbentuknya rekomendasi dari mulut ke mulut yang kesemuanya menguntungkan perusahaan. Menurut Sangadji dan sopian (2013:180) bahwa "Kepuasan adalah perasaaan senang atau kecewa seseorang yang berasal dari perbandingan antara kesannya terhadap kinerja produk yang riil/ aktual dengan kinerja produk yang diharapkan.

\section{g. Faktor-Faktor Yang Mempengaruhi Kepuasan Pelanggan}

Menurut Tjiptono dalam Enny Widayati (2010:8) bahwa ketidakpuasan pelanggan disebabkan oleh faktor internal dan faktor eksternal. Faktor internal yang relatif dapat dikendalikan perusahaan, misalnya karyawan yang kasar, jam karet, kesalahan pencatatan transaksi. 
Sebaliknya, faktor eksternal yang diluar kriminal, dan masalah pribadi pelanggan. Faktor pendukung yang tidak kalah pentingnya dengan kepuasan diantaranya faktor kesadaran para pejabat atau petugas yang berkecimpung dalam pelayanan umum, faktor aturan yang menjadi landasan kerja pelayanan, faktor organisasi yang merupakan alat serta sistem yang memungkinkan berjalannya mekanisme kegiatan pelayanan, faktor pendapatan yang dapat memenuhi kebutuhan hidup minimum, faktor keterampilan petugas, dan faktor sarana dalam pelaksanaan tugas pelayanan.

\section{h.Indikator Kepuasan Pelanggan}

Menurut Vincent Gasperz dalam Poedji Astoeti (2016:29) agar pelayanan dapat memuaskan orang atau kelompok orang yang dilayani, maka pelaku yang bertugas melayani harus memenuhi 5 (lima) kriteria pokok yaitu sebagai berikut :

1. Keistimewaan

2. Daya tarik

3. Memenuhi Keinginan Masyarakat

4. Memberi Kesenangan

5. Bebas dari kekurangan atau kerusakan

\section{Metodologi Penelitian}

Metode penelitian kuantitatif peneliti menentukan kuota sebesar 100 orang artinya sampel dalam penenlitian ini berjumlah 100 orang, dimana 100 orang tersebut merupakan masyarakat yang dilayani oleh Dinas Tenaga Kerja Kabupaten Tangerang dalam pembuatan kartu kuning setiap harinya.

\section{Operasional Variabel}

Operasional variabel diperlukan guna menentukan jenis dan indikator dari variabelvariabel yang terkait dalam penelitian ini. Disamping itu operasional variabel yang bertujuan untuk menentukan skala pengukuran dari masing-masing variabel, sehingga pengujian hipotesis dengan menggunakan alat bantu dapat dilakukan dengan tepat.

\section{Instrumen Penelitian}

\section{a. Jenis dan Sumber Penelitian}

Data Primer adalah data yang diambil langsung oleh peneliti kepada sumbernya tanpa perantara. Peneliti mencari dan menemukan data kepada informan baik wawancara maupun pengamatan langsung dilapangan. Data Sekunder adalah sumber tidak langsung, yang mampu memberikan tambahan serta penguatan terhadap penelitian. Sumber data sekunder ini dapat berupa buku, majalah ilmiah, sumber dari arsip, dokumen pribadi, dan dokumen resmi. 


\section{b. Teknik Pengumpulan Data}

\section{Metode observasi}

Menurut Sugiyono (2010:310) observasi merupakan suatu proses yang komples, suatu proses tersusun dari berbagai proses biologis maupun psikologis. Teknik ini di gunakan apabila penelitian berkenaan dengan perilaku manusia, proses kerja, gejala- gejala alam, dan bila responden yang diamati tidak terlalu besar.

2. Wawancara

Menurut Sugiyono (2016:137) mengatakan "Wawancara adalah teknik pengumpulan data apabila peneliti ingin melakukan studi pendahuluan untuk menemukan permasalahan yang harus diteliti, dan juga apabila peneliti ingin mengetahui hal-hal dari responden yang lebih mendalam dan jumlah respondennya sedikit/ kecil.

\section{Kuesioner atau Angket}

Menurut Sugiyono (2016:42) mengatakan Kuesioner atau angket merupakan teknik pengumpulan data yang dilakukan dengan cara memberi seperangkat pertanyaan atau pertanyaan tertulis kepada responden untuk dijawabnya.

4. Dokumentasi

Metode ini merupakan suatu cara pengumpulan data yang menghasilkan catatan-catatan penting yang berhubungan dengan masalah yang diteliti, sehingga akan diperoleh data yang lengkap, sah dan bukan berdasarkan perkiraan.

\section{Uji Validitas, Reliabilitas, dan Uji Normalitas}

\section{a. Uji Validitas}

Uji Validitas menurut Sugiyono (2009:172) adalah suatu data dapat di percaya kebenarannya sesuai dengan kenyataan. Menurut Sugiyono (2016:121) mengatakan "Valid berarti instrumen tersebut dapat digunakan untuk mengukur apa yang harus diukur". Instrumen yang valid berarti alat ukur yang digunakan untuk mendapatkan data (mengukur) itu valid. Adapun dasar pengambilan keputusan untuk uji validitas adalah sebagai berikut :

- Bila $r$ hitung > r tabel, maka Ha diterima. Artinya Valid

- Bila r hitung < r tabel, maka Ha ditolak.

Artinya tidak Valid

\section{b. Uji Reliabilitas}

Menurut Sugiyono (2016:172) mengatakan “Uji reliabilitas digunakan untuk mengetahui apakah alat pengumpulan data menunjukan tingkat ketepatan, tingkat keakuratan, kestabilan, atau konsistensi dalam mengungkapkan gejala tertentu. Uji reliabilitas harus dilakukan hanya pada pernyataan-pernyataan yang sudah memenuhi uji validitas dan yang tidak memenuhi, maka 
tidak perlu diteruskan untuk di uji reliabilitas

a. Jika $r$ hitung $>\mathrm{t}$ tabel Ho di tolak, artinya reliable

b. Jika $r$ hitung $<\mathrm{t}$ tabel Ho di terima, artinya tidak reliable

\section{c. Uji Normalitas}

Penggunaan statistik parametris, bekerja dengan asumsi bahwa setiap variabel penelitian yang akan dianalisis membentuk distribusi normal. Bila data tidak normal, maka teknik statistik parametris tidak dapat digunakan untuk analisis, untuk itu sebelum dianalisisnya, maka penulis harus membuktikan terlebih dahulu, apakah data yang akan dianalisis itu berdistribusi normal atau tidak.

Teknik Analisis Data dan Pengujian Hipotesis

\section{a. Uji Koefisien Korelasi}

Menurut Subagio (2004:164) mengatakan "Korelasi adalah koefisien yang mengukur hubungan antara dua variabel atau lebih". Syarat korelasi product moment yaitu : data distribusi normal, data linier (searah), data yang di pilih secara acak (random), variasi skor variabel yang dihubungkan harus dan interval atau rasio. Selanjutnya, uji koefisien korelasi ini digunakan untuk mengetahui derajat pengaruh antara variabel bebas dengan variabel terkait. Pengujian Korelasi menggunakan rumus product moment pearson sebagai berikut :

$$
\left\{n \Sigma x_{i}^{2}-\Sigma x_{i}^{2}\right\}\left\{n \Sigma y_{i}^{2}-\left(\Sigma y_{i}\right)^{2}\right\}
$$

$$
r_{x y}=\frac{n \Sigma x_{i} y_{i} \quad\left(\Sigma x_{i}\right)\left(\Sigma y_{i}\right)}{}
$$

\section{Keterangan :}

$r_{x y}=$ Koefisien korelasi product moment (korelasi antara $\mathrm{x}$ dan $\quad$ y) $n \quad=$ Jumlah sampel, banyaknya pasangan skor x dan y

$\mathrm{X}=$ Skor dalam distribusi variabel $\mathrm{X}_{1}$ dan $\mathrm{X}_{2}$

$\mathrm{Y}=$ Skor dalam distribusi variabel $\mathrm{Y}$

$\sum \mathrm{X}^{2}=$ Kuadrat jumlah skor $\mathrm{X}$

$\sum \mathrm{Y}^{2}=$ Kuadrat jumlah skor $\mathrm{Y}$

\section{b. Uji Koefisien Determinasi $\left(r^{2}\right)$}

Koefisien Determinasi (KD) digunakan untuk melihat seberapa besar variabel independen (X) berpengaruh terhadap variabel dependen (Y) yang di nyatakan dalam persentase. Koefisien determinasi di hitung dengan mengkuadratkan koefisien korelasi yang telah di tentukan dan selanjutnya di kalikan dengan 100\%. Koefisien determinasi (penentu) dinyatakan dengan Rumus: 


$$
\mathrm{KD}=\mathrm{r}^{2} \times 100 \%
$$

Keterangan :

$\mathrm{KD}=$ Koefisien Determinasi $\mathrm{r}^{2} \quad=$ Koefisien Korelasi

\section{c. Uji Regresi Linier Sederhana}

Analisis regresi linier sederhana digunakan untuk mendapatkan hubungan matematis dalam bentuk suatu persamaan antara variabel tak bebas dengan variabel bebas tunggal. Analisis ini di gunakan untuk menguji bagaimana pengaruh variabel independen $(\mathrm{X})$ terhadap variabel dependen

(Y) yang di rumuskan sebagai berikut

$$
\dot{Y}=a+b X
$$

Keterangan

$\hat{Y} \quad=$ Subyek dalam variabel terikat yang prediksi

a = Harga Y bila $\mathrm{X}=0$ (harga konstan)

$\mathrm{b}$ = Angka arah atau koefisien regresi, yang menunjukan angka peningkatan

ataupun penurunan variabel dependen yang di dasarkan pada variabel independen. Bila b (+) maka naik, bila (-) maka $\mathrm{X}=$ Subyek pada variabel independen yang mempunyai nilai tertentu.

\section{d. Uji Hipotesis ( $t$ hitung)}

Pengujian hipotesis dimaksud untuk mengetahui ada tidaknya pengaruh yang signifikan antara variabel independen dengan variabel dependen. Dalam pengujian hipotesis ini, peneliti menetapkan dengan uji signifikan, dengan penetapan hipotesis nol $\left(\mathrm{H}_{0}\right)$ dan hipotesis alternatif $\left(\mathrm{H}_{\mathrm{a}}\right)$.

$$
t_{\text {hitung }}=r \overline{\overline{1 r^{2}}}
$$

Keterangan :

$\mathrm{t}=$ Signifikan hubungan $\mathrm{n}=$ Sampel

$r=$ Koefisien Korelasi $r=$ Koefisien Korelasi

Untuk mengetahui apakah uji hipotesis yang dirumuskan dapat diterima atau ditolak, 
maka dirumuskan sebagai berikut :

- Hipotesis Ho (Hipotesis Nol) Jika thitung $>$ tabel Ho ditolak

Ha diterima (ada pengaruh variabel Xterhadap Y yang Signifiłan)

- Hipotesis Ha (Hipotesis Alternatif) Jika thitung $>t_{\text {tabel }}=>$ Ho diterima

Ha ditolak (tidak ada pengaruh variabel $\mathrm{X}$ terhadap Y yang signifikan)

\section{HASIL PENELITIAN DAN PEMBAHASAN}

\section{A. Variabel X (Kualitas Pelayanan)}

\section{Bukti Langsung (Tangible)}

Berdasarkan hasil data oleh peneliti kepada sejumlah responden bahwa responden menjawab baik (46\%) terhadap tingkat bukti langsung (tangible) para aparatur yang ada pada Dinas Tenaga Kerja Kabupaten Tangerang.

\section{Kehandalan (Reliability)}

Berdasarkan hasil data oleh peneliti kepada sejumlah responden, bahwa rata-rata responden menjawab baik (54\%) terhadap tingkat kehandalan (reliability) para aparatur yang ada pada Dinas Tenaga Kerja Kabupaten Tangerang.

\section{Daya Tanggap (Responsiveness)}

Berdasarkan hasil data oleh peneliti kepada sejumlah responden bahwa responden menjawab cukup baik (38\%) terhadap tingkat kehandalan (reliability) para aparatur yang ada pada Dinas Tenaga Kerja Kabupaten Tangerang.

\section{Jaminan (Assurance)}

Berdasarkan hasil data oleh peneliti kepada sejumlah responden bahwa rata-rata responden menjawab cukup baik (52\%) terhadap tingkat jaminan (assurance) para aparatur yang ada pada Dinas Tenaga Kerja Kabupaten Tangerang.

\section{Empati (Empaty)}

Berdasarkan hasil data oleh peneliti kepada sejumlah responden bahwa responden menjawab baik (35\%) terhadap tingkat empati (empaty) para aparatur yang ada pada Dinas Tenaga Kerja Kabupaten Tangerang.

\section{B. Variabel Y (Kepuasan Masyarakat)}

\section{Keistimewaan}

Berdasarkan hasil data oleh peneliti

kepada sejumlah responden bahwa rata-rata responden menjawab cukup baik (50\%) terhadap tingkat keistimewaan para aparatur yang ada pada Dinas Tenaga Kerja Kabupaten Tangerang. 


\section{Daya Tarik}

Berdasarkan hasil data oleh peneliti kepada sejumlah responden bahwa responden menjawab baik (39\%) terhadap tingkat daya tarik para aparatur yang ada pada Dinas Tenaga Kerja Kabupaten Tangerang.

\section{Memenuhi Keinginan Masyarakat}

Berdasarkan hasil data oleh peneliti kepada sejumlah responden, bahwa responden menjawab cukup baik (50\%) terhadap tingkat memenuhi keinginan masyarakat para aparatur yang ada pada Dinas Tenaga Kerja Kabupaten Tangerang.

\section{Memberi Kesenangan}

Berdasarkan hasil data oleh peneliti kepada sejumlah responden bahwa responden menjawab cukup baik (48\%) terhadap tingkat memberi kesenangan para aparatur yang ada pada Dinas Tenaga Kerja Kabupaten Tangerang.

\section{Bebas Dari Kekurangan dan Kerusakan}

Berdasarkan hasil data oleh peneliti kepada sejumlah responden, maka dapat disimpulkan bahwa responden menjawab baik (39\%) terhadap tingkat bebas dari kekurangan dan kerusakan para aparatur yang ada pada Dinas Tenaga Kerja Kabupaten Tangerang.

\section{E. KESIMPULAN DAN SARAN}

\section{a. Kesimpulan}

Berdasarkan hasil pembahasan tentang Pengaruh Kualitas Pelayanan Terhadap Kepuasan Masyarakat Pembuat Kartu Kuning (AK-I) Pada Dinas Tenaga Kerja Kabupaten Tangerang sebagaimana yang telah diuraikan, maka peneliti dapat menarik kesimpulan sebagai berikut :

1. Hasil penelitian menunjukan bahwa Kualitas Pelayanan dinilai baik yaitu sebesar 0,76 atau $\quad 76 \%$ dari kriteria yang ditetapkan berdasarkan rekapitulasi hasil penelitian dari variabel independen.

2. Hasil penelitian menunjukan bahwa Kepuasan Masyarakat Pembuat Kartu Kuning (AKI) pada Dinas Tenaga Kerja Kabupaten Tangerang dinilai baik yaitu sebesar 0,71 atau $71 \%$ dari kriteria yang ditetapkan berdasarkan rekapitulasi hasil penelitian dari variabel dependen.

3. Hasil penelitian menunjukan variabel Kualitas Pelayanan Terhadap Kepuasan Masyarakat Pembuat Kartu Kuning (AK-I) memberi pengaruh terhadap varibael Kualitas Pelayanan sebesar 22,1\% dan 77,9\% masih dipengaruhi faktor lain. 


\section{b. Saran}

Berdasarkan hasil kesimpulan tersebut, peneliti mencoba memberikan saran sebagai masukan kepada Dinas Tenaga Kerja Kabupaten Tangerang sebagai berikut :

1. Perlu penataan sarana dan prasarana proses pelayanan agar dapat memberikan rasa nyaman kepada masyarakat pembuat kartu kuning (AK-I) dengan menambahkan fasilitas ruang tunggu yang nyaman, untuk mengatasi rasa jenuh dalam menunggu antrian dan Dinas Tenaga Kerja Kabupaten Tangerang sudah sepatutnya memiliki mesin photo copy sendiri dipelayanannya karena selama ini masyarakat harus pergi keluar berjalan kaki untuk melakukan legalisir dengan memphoto copy yang bisa memakan waktu cukup lama.

2. Untuk memperlancar proses pelayanan pembuatan kartu kuning (AK-I) diupayakan adanya penambahan loket pelayanan baru, sehingga terciptanya pelayanan yang efektif dan efisien.

3. Semua petugas pelayanan agar dapat memberikan pelayanan dengan lebih ramah kepada seluruh masyarakat pembuat kartu kuning (AK-I) tanpa membeda-bedakan memahami dan menyadari bahwa kepuasan masyarakat merupakan tujuan utama yang harus dicapai sehingga masing- masing individu berpartisipasi aktif untuk mewujudkan kepuasan masyarakat dengan meningkatkan kedisiplinan kerja dan memberikan pelayanan yang lebih ramah.

\section{Daftar Pustaka}

Astia, Tia, 2015. "Pengaruh Kualitas Pelayanan Terhadap Kepuasan Masyarakat Pada Kantor Camat Tanjungpinang Timur", Program Studi Administrasi Negara, Fakultas Ilmu Sosial Dan Ilmu Politik Universitas Maritim Raja Ali Haji Tanjungpinang.

Astoeti, Poedji P.A, 2016. "Pengaruh Pelayanan Terpadu Satu Pintu Terhadap Kepuasan Masyarakat Di Kecamatan Kelapa Gading Jakara Utara Tahun 2015”, Jurusan Administrasi Negara Fakultas Ilmu Sosial Dan Ilmu Politik Universitas Nasional.

Atmosudirjo, Prajudi, 1990, Dasar-dasar Administrasi Negara, Jakarta :Ghalia Indonesia

Hardiyansyah,2018, Kualitas Pelayanan Publik, Konsep, Dimensi, Indikator dan Impelementasinya, Yogyakarta:GavaMedia

Hasibuan, Malayu S.P, 2011, Manajemen Dasar, Pengertian, Dan Masalah Edisi: Revisi, 
Jakarta : Bumi Aksara

Hidayat, Toni, 2018.’Pengaruh Kualitas Pelayanan Pembuatan Akta Kelahiran Terhadap Kepuasan Masyarakat Pada Kantor Dinas Kependudukan Dan Pencatatan Sipil Kabupaten Tangerang”, Fakultas Ilmu Sosial Dan Ilmu Politik Universitas Islam Syekh Yusuf Tangerang.

Hipludin, Agus, 2017, Kebijakan, Birokrasi, dan Pelayanan Publik, Tinjauan Kritis Ilmu Administrasi Negara, Yogyakarta:CALPULIS

Kencana,Inu.2015. Sistem Administrasi Negara Republik Indonesia (SANKRI), Jakarta: PT Bumi Aksara

Khusaini, Ahmad. 2016 “Analisis Kualitas Pelayanan Terhadap Kepuasan Konsumen Di SPA Club Arena Yogyakarta”, Program Studi Ilmu Keolahragaan Fakultas Keolahragaan Universitas Negeri Yogyakarta.

Musnianti,Indah. 2010 "Kualitas Pelayanan Pembuatan Kartu Kuning Di Kantor Pelayanan Terpadu Dinas Tenaga Kerja dan Transmigrasi Kabupaten Tangerang”, Program Studi Ilmu Administrasi Negara Fakultas Ilmu Sosial dan Ilmu Politik Universitas Sultan Ageng Tirtayasa Serang.

Nugraheni, Arif Z.A. 2015 “Analisis Kepuasan Masyarakat Terhadap Pelayanan Publik berdasarkan Indeks Kepuasan Masyarakat Di Kantor Kecamatan Mungkid Kabupaten Magelang",Program Studi Pendidikan Administrasi Perkantoran Jurasan Pendidikan Admninistrasi, Fakultas Ekonomi Universitas Negeri Yogyakarta.

Nuraeni, 2016. "Pengaruh Kualitas Pelayanan PT.PLN (Persero) Terhadap Kepuasan Pelanggan Di Kabupaten Sinjai (Studi Kasus Pelanggan Rumah Tangga Tarif 900 Va)”, Fakultas Ilmu Sosial Universitas Negeri Makassar.

Nurgiyanto, Gunawan, dan Marzuki. 2009. Statistik Terapan. Yogyakarta :Gadjah Mada University Press.

Sangadji dan Sopian,2013, Perilaku Konsumen, Yogyakarta: Penerbit ANDI

Siregar, Doni Edwin.2012.’Evaluasi Tingkat Kepuasan Masyarakat Terhadap Pembangunan Jalan diKelurahan Dwikora Kecamatan Medan Helvesia Kota Medan Tahun 2012”, Jurnal Administrasi Publik, JAP Vol. 3, No. 1, Juni 2015 
Sinambela, Lijan Poltak, 2014, Reformasi Pelayanan Publik, Teori,Kebijakan, dan Implementasi, Jakarta : PT Bumi Aksara

Sugiyono, 2016, Metode Penelitian Kuantitatif, Kualitatif, dan $R \& D$, Bandung : Alfabeta

Widayati, Eni.2010. “Anaisis Pengaruh Dimensi Kualitas Pelayanan Penempatan Tenaga Kerja Terhadap Kepuasan Pencari Kerja (Studi Pada Dinas Tenaga Kerja Dan Transmigrasi Kota Surabaya)", Program Pascasarjana Magister Manajemen Universitas Dian Nuswantoro Semarang.

Yusri, 2013. Statistik Sosial Aplikasi dan Interpretasi, Yogyakarta :GRAHA ILMU

Yuwono, 2012. “Analisis Kualitas Pelayanan Terhadap Kepuasan Pelanggan Pada Hotel Sewu Mas Yogyakarta".

Dokumen-Dokumen

AL-QUR'AN surat Al-Baqarah ayat 267

Undang-Undang Nomor 25 Tahun 2009 tentang Pelayanan Publik

Keputusan Menteri Pendayagunaan Aparatur Negara Nomor 63/KEPM.PAN/7/2003 Tentang Pedoman Umum Penyelenggara Pelayanan Publik 